Efficient Vol 1 (2) (2018): 126-134. DOI: https://doi.org/10.15294/efficient.vii2.27613
Indonesian Journal of Development Economics
http: https://journal.unnes.ac.id/sju/index.php/efficient

\title{
Strategi Realisasi Usulan Hasil Musrenbang dalam RKPD di Kecamatan Candisari Kota Semarang
}

\author{
Novi Megawati ${ }^{\square}$, Yozi Aulia Rahman² \\ Jurusan Ekonomi Pembangunan,Fakultas Ekonomi, Universitas Negeri Semarang \\ Permalink/DOI: https://doi.org/10.15294/efficient.vii2.27613 \\ Received: January 2018; Accepted: March 2018; Published: Juny 2018
}

\begin{abstract}
The aims of this research is to find out and identify the cause of the low result realization of musrenbang and to determine the strategy of increasing the result realization of musrenbang in RKPD of Candisari District Semarang City. The methods used in this research is descriptive and AHP (Analytical Hierarchy Process). The Informants of this research are 10 keypersons consisting of the community representations, the sub-district representations and the district representations. The results of the research by using analytical hierarchy process shows that the strategy of increasing the result realization of musrenbang consist of some programs criteria which prioritised that are human resource aspect, regulation aspect and budget aspect. The Alternative of priority program is by giving socialization to the community before committing of musrenbang. Furthermore, it creates a sense of community ownership in the management of local government, and ensures the existence of transparency, accountability and public interest.
\end{abstract}

Keywords: Strategy, Increasing, Musrenbang realization, RKPD, Analytical Hierarchy Process

\begin{abstract}
Abstrak
Penelitian ini bertujuan untuk mengetahui dan mengidentifikasi penyebab dari rendahnya realisasi usulan hasil musrenbang dalam RKPD serta menentukan strategi peningkatan realisasi usulan hasil musrenbang dalam RKPD Kecamatan Candisari Kota Semarang. Penelitian ini menggunakan alat analisis deskriptif dan AHP (Analytical Hierarchy Process). Informan dari penelitian ini terdiri dari to keyperson yang terdiri dari unsur perwakilan masyarakat, kelurahan, kecamatan. Hasil penelitian menunjukkan bahwa strategi peningkatan realisasi usulan hasil musrenbang terdiri atas beberapa kriteria program yang diprioritaskan yaitu aspek sumber daya manusia, aspek regulasi dan aspek anggaran. Alternatif prioritas program yaitu dengan pemberian sosialisasi kepada masyarakat sebelum musrenbang dilaksanakan. Selanjutnya yaitu menciptakan rasa memiliki masyarakat dalam pengelolaan pemerintah daerah, serta menjamin terdapatnya transparansi, akuntabilitas dan kepentingan umum.
\end{abstract}

Kata Kunci: Strategi, Peningkatan, Realisasi Musrembang, RKPD, Analytical Hierarchy Process

How to Cite: Megawati, N., \& Rahman, Y. (2018). Strategi Realisasi Usulan Hasil Musrenbang dalam RKPD di Kecamatan Candisari Kota Semarang. EFFICIENT Indonesian Journal of Development Economics, 1(2), 126-134. https://doi.org/10.15294/efficient.vii2.27613

(C) 2018 Semarang State University. All rights reserved

Alamat Korespondensi :

Alamat: Gedung L2 Lantai 2 FE Unnes

Kampus Sekaran, Gunungpati, Semarang, 50229

E-mail : jurnalefficient@gmail.com 


\section{PENDAHULUAN}

Perkembangan keberhasilan sistem bottom-up dapat dilihat dari bagaimana peran serta masyarakat dalam musrenbang, bukan hanya masalah kehadiran dalam proses musrenbang melainkan juga bagaimana masyarakat mampu mengajukan dan menilai program usulan mana yang pantas dan layak untuk diusulkan untuk menjadi prioritas, dalam hal ini terkait dengan kualitas usulan yang diajukan oleh masyarakat. Realisasi hasil dari musrenbang dalam RKPD sangat penting mengingat hal ini adalah bukti bahwa kegiatan musrenbang yang mengadopsi sistem bottom-up berjalan dengan baik atau tidak. Kota Semarang mempunyai tingkat persentase realisasi musrenbang dalam RKPD yang tinggi. Untuk lebih jelasnya dapat dilihat dari tabel 1 berikut:

Tabel 1. Persentase Realisasi Usulan Hasil Musrenbang dalam RKPD

\begin{tabular}{|c|c|c|c|c|c|}
\hline \multirow{3}{*}{ No } & \multirow{3}{*}{ Kecamatan } & \multirow{2}{*}{\multicolumn{4}{|c|}{$\begin{array}{l}\text { Persentase Realisasi } \text { Usulan } \\
\text { Musrenbang Dalam RKPD }\end{array}$}} \\
\hline & & & & & \\
\hline & & 2014 & 2015 & 2016 & 2017 \\
\hline 1 & Semarang Selatan & $50.47 \%$ & $70.62 \%$ & $94.65 \%$ & $91.76 \%$ \\
\hline 2 & Semarang Utara & $36.03 \%$ & $52.82 \%$ & $96.61 \%$ & $97.65 \%$ \\
\hline 3 & Semarang Barat & $63.95 \%$ & $95.26 \%$ & $100.00 \%$ & $97.81 \%$ \\
\hline 4 & Semarang Timur & $62.21 \%$ & $64.43 \%$ & $97.69 \%$ & $94.97 \%$ \\
\hline 5 & Semarang Tengah & $50.44 \%$ & $67 \cdot 39 \%$ & $95 \cdot 90 \%$ & $93.62 \%$ \\
\hline 6 & Gunungpati & $49.04 \%$ & $55.19 \%$ & $85.63 \%$ & $83.95 \%$ \\
\hline 7 & Tugu & $43.17 \%$ & $54 \cdot 55 \%$ & $100.00 \%$ & $100.00 \%$ \\
\hline 8 & Mijen & $59 \cdot 38 \%$ & $84.98 \%$ & $96.20 \%$ & $96.05 \%$ \\
\hline 9 & Genuk & $36.43 \%$ & $57.14 \%$ & $99.03 \%$ & $92.43 \%$ \\
\hline 10 & Gajahmungkur & $46.09 \%$ & $62.92 \%$ & $98.72 \%$ & $89.82 \%$ \\
\hline 11 & Tembalang & $30.15 \%$ & $51.82 \%$ & $95.13 \%$ & $97.25 \%$ \\
\hline 12 & Candisari & $97.89 \%$ & $74.09 \%$ & $91.43 \%$ & $69.41 \%$ \\
\hline 13 & Banyumanik & $54.88 \%$ & $80.00 \%$ & $93.12 \%$ & $92.42 \%$ \\
\hline 14 & Ngaliyan & $61.99 \%$ & $89.80 \%$ & $93 \cdot 55 \%$ & $90.48 \%$ \\
\hline 15 & Gayamsari & $35 \cdot 71 \%$ & $46.40 \%$ & $89 \cdot 36 \%$ & $92.00 \%$ \\
\hline 16 & Pedurungan & $25.61 \%$ & $39.48 \%$ & $97.16 \%$ & $97 \cdot 30 \%$ \\
\hline
\end{tabular}

Sumber : Bappeda Kota Semarang (2017)

Berdasarkan tabel 1 diatas dapat pembangunan yang telah ditetapkan oleh disimpulkan bahwa usulan masyarakat ditampung baik oleh pemerintah setempat. Dari tahun 2014 sampai tahun 2016 persentase usulan yang terealisasi mengalami kenaikan. Membuktikan bahwa dari 2014 sampai tahun 2016 kualitas usulan program pembangunan dalam musrenbang sudah sesuai dengan visi dan misi pemerintah. Hal berbeda ditemui pada tahun 2017 yang walaupun memiliki angka persentase yang juga tinggi tetapi realisasi mengalami penurunan yang cukup signifikan, dimana hanya terdapat lima kecamatan yang mengalami kenaikan realisasi musrenbang yaitu kecamatan Pedurungan, Semarang Utara, Tugu, Tembalang 
dan Gayamsari. Kecamatan yang mengalami penurunan persentase realisasi musrenbang meliputi kecamatan Semarang Selatan, Semarang Barat, Semarang Timur, Semarang tengah, Gunungpati, Mijen, Genuk, Gajahmungkur, Candisari, Banyumanik, dan Ngaliyan.

Dari tahun 2014 sampai dengan 2017 ratarata presentase kecamatan mengalami kenaikan. Kecamatan Candisari merupakan satu-satunya kecamatan yang mempunyai tren tidak stabil dalam presentase realisasi musrenbang dalam RKPD. Dimana pada tahun 2014 Kecamatan Candisari menjadi Kecamatan dengan realisasi paling tinggi, pada tahun 2015 mengalami penurunan, 2016 mengalami kenaikan dan pada tahun 2017 mengalami penurunan yang sangat signifikan dan menjadi kecamatan dengan tingkat realisasi musrenbang dalam RKPD yang paling rendah. Kecamatan Candisari mengalami fluktuasi besaran persentase realisasi usulan hasil musrebang. Hal ini membuat penulis ingin menganalisis secara lebih dalam mengenai realisasi usulan hasil musrenbang dalam RKPD di Kecamatan Candisari Kota Semarang.

Pembangunan menurut Mardikanto dan Soebianto (2012) dalam Asnar (2016) adalah sesuatu yang dari, oleh, dan untuk masyarakat, sehingga pembangunan mensyaratkan pelibatan atau partisipasi seluruh warga masyarakat, dari sejak pengambilan keputusan, sampai pada pelaksanaan dan pengawasan kegiatan, serta pemanfaatan hasil-hasilnya oleh masyarakat. Pembangunan, bukanlah kegiatan yang dilaksanakan oleh pemerintah untuk masyarakatnya, akan tetapi kegiatan yang dilaksanakan pemerintah bersama-sama seluruh warga masyarakatnya. Sarwono (2016) dalam Rusdiarti (2016) mengungkapkan bahwa pembangunan di suatu daerah pada dasarnya adalah upaya untuk meningkatkan kapasitas pemerintah, sektor swasta, masyarakat, dan pemangku kepentingan terkait dalam pengelolaan sumber daya ekonomi di efisien dan efektif cara untuk kemajuan daerah dan kesejahteraan sosial

Pembangunan daerah dilaksanakan untuk meningkatkan pemerataan penyebaran pembangunan nasional di seluruh wilayah (Berliana, 2017). Pembangunan daerah merupakan pembangunan yang dimaksudkan untuk mendorong, memberdayakan masyarakat, menumbuhkan prakarsa serta meningkatkan partisipasi masyarakat dalam rangka membangun daerahnya, dan meningkatkan kesejahteraan masyarakat (Rahman, 2015).

Dalam pembangunan daerah dibutuhkan partisipasi masyarakat untuk bersama membangun daerah. Terdapat beberapa macam strategi partisipasi merurut Burke (2004) dalam Putra (2016) diantaranya, Pertama Terapi pendidikan (Education Therapy) dimana strategi ini lebih memusatkan pada peningkatan kemampuan peserta secara individu. Adapun sasarannya adalah sebagai berikut : Meningkatkan kompetisi dan kapasitas masyarakat, Kegiatan ini dilakukan dalam bentuk pelatihan atau pembelajaran bagi masyarakat dimana masyarakat belajar memecahkan permasalahan melalu cara demokrasi, saling menghargai dan bekerja sama.

Kedua Kemitraan (Cooptation), Bentuk lain dari partisipasi masyarakat adalah melibatkan masyarakat dalam organisasi untuk mengantisipasi kendala yang ada. Dalam hal ini masyarakat tidak dipandang sebagai alat untuk mencapai tujuan, melainkan sebagai mitra yang akan membentuk organisasi dalam mencapai tujuan, strategi ini digambarkan sebagai proses 
menarik elemen ke dalam kebijakan atau kepemimpinan suatu organisasi serta sebagai alat untuk mengalihkan atau mencegah ancaman yang dapat menganggu keberadaannya.

Ketiga adalah Kekuatan masyarakat (Community Power). Kebanyakan organisasi masyarakat menggunakan kekuasaannya untuk mempengaruhi keputusan masyarakat. Ada dua strategi partisipasi masyarakat yang didasarkan pada teori kekuataan masyarakat, keduanya dirancang untuk memanfaatkan kekuataan masyarakat, yaitu : merekrut individu yang memiliki pengaruh dalam menganugerahkan kuasa dan pengaruh pada pengaruh organisasi tersebut, dan menganugerahkan penghargaan pada anggotanya.

Halimah (2012) dalam penelitian terdahulu menyatakan bahwa, Pelaksanaan musrenbang sudah terlaksana dengan baik, tetapi belum sepenuhnya sesuai dengan apa yang menjadi keinginan dan kebutuhan masyarakat. Hal ini dikarenakan pada tahapan yang lebih tinggi, yaitu musrenbang kabupaten, prioritas usulan kegiatan yang disampaikan oleh masing-masing desa/kelurahan harus disingkronkan dengan program pembangunan SKPD yang notabene bersifat Top-Down. Kurang makismalnya musrenbang tersebut dipengaruhi oleh faktor keakuratan usulan kegiatan, faktor minimnya pendampingan, faktor kurangnya transparansi pelaksanaan musrenbang, dan faktor anggaran.

Penelitian ini bertujuan untuk mengetahui dan mengidentifikasi penyebab dari rendahnya realisasi usulan hasil musrenbang dalam RKPD serta menentukan strategi peningkatan realisasi usulan hasil musrenbang dalam RKPD Kecamatan Candisari Kota Semarang.

\section{METODE PENELITIAN}

Jenis penelitian yang digunakan dalam penelitian ini adalah penelitian kualitatif. Data yang digunakan dalam penelitian ini adalah jenis data primer dan sekunder. Data primer merupakan data yang dikumpulkan dan diolah sendiri oleh organisasi yang menerbitkan atau menggunakan. Sedangkan data primer untuk perumusan strategi dalam Analisis Hierarki Proses (AHP) diperoleh dari key persons, meliputi penentuan kriteria dalam meningkatkan realisasi usulan hasil musrenbang Kecamtan Candisari Kota Semarang. Data sekunder yaitu data yang diperoleh dari instansi terkait, yiatu Badan Perencanaan dan Pembangunan (Bappeda), Kantor Kecamatan Candisasi, dan lain sebagainnya.

Penelitian ini menggunakan teknik analisis deskriptif dan Analisis Hierarki Proses (AHP). AHP digunakan dengan tujuan untuk mengetahui strategi manakah yang perlu didahulukan atau diprioritaskan dalam upaya meningkatkan realisasi usulan hasil musrenbang. Oleh karena itu penelitian ini membutuhkan beberapa pihak yang dianggap berkompeten (key-persons) yang mewakili untuk menetukan alternatif-alternatif program.

\section{HASIL DAN PEMBAHASAN}

Tidak adanya keakuratan usulan yang dimaksud adalah masyarakat yang belum begitu bisa membedakan mana kebutuhan dan keinginan. Keinginan dapat diartikan sebagai segala sesuatu yang diinginkan seseorang yang apabila tidak terpenuhi tidak akan mengganggu kelangsungan hidup orang tersebut. Berbeda dengan kebutuhan yang berarti segala sesuatu 
yang dibutuhkan oleh seseorang yang apabila tidak terpenuhi akan mengganggu kelangsungan hidup orang tersebut.

Dalam penelitian sebelumnya Supadmi (2013) mengungkapkan bahwa setiap perwakilan/delegasi tentu menginginkan usulan yang mereka bawa mesti diprioritaskan. Rasa egoisme masing-masing pihak pasti ada sebagai manusia yang tidak sempurna. Rasa curiga, prasangka yang kurang baik serta egoism tersebut akan dapat ditekan apabila para peserta telah bersepakat dengan kriteriakriteria yang telah ditentukan.

Usulan yang sesuai dengan kebutuhan harus memiliki aspek sosial bukan hanya bentuk egoisme semata, hal ini seperti yang dikemukakan oleh Diana Conyers (1994:5) dalam Sanjayani (2016) bahwa

"every single planning must be having implication or social aspect, therefore it can be considered that social planning has to be a form of direction for all the series of planning activity itself."

Pemahaman masyarakat akan potensi dan masalah daerah tempat mereka tinggal sangat penting dalam pengajuan usulan program di musrenbang. Pemahaman ini jelas akan membuat lebih mudah menentukan kebutuhan apa yang daerah mereka butuhkan bukan hanya sekedar keinginan tanpa mengenali potensi dan masalah daerah itu sendiri.

Masyarakat diperlukan untuk mengenali masalah daerah tempat mereka tinggal dan memberikan usulan program pembangunan sesuai sistem bottom-up yang digalakan. Oleh karena itu edukasi (pemberian pendidikan) dan sosialisasi bagi masyarakat maupun fasilitatorfasilitator penyelenggara musrenbang diperlukan. Agar musrenbang bukan hanya sekedar formalitas dalam sistem bottom-up tapi merupakan bukti nyata dalam sistem pembangunan yang berasal dari masyarakat. Hal ini sesuai dengan strategi partisipasi menurut Burke (2004) dalam Putra (2016) dimana terapi pendidikan dapat menjadi solusi untuk meningkatkan partisipasi masyarakat secara aktif. Masyarakat diberi pelatihan atau pembelajaran untuk memecahkan permasalahan melalui cara demokrasi, saling menghargai dan bekerja sama. Hal yang sama juga dikemukakan oleh Conyers (1994) dalam Wirawan (2015) menyatakan bahwa dalam hasil kegiatan musrenbang diperlukan partisipasi masyarakat. Partisipasi masyarakat merupakan alat guna memperoleh informasi mengenai kondisi, kebutuhan dan sikap masyarakat setempat, yang tanpa kehadiran masyarakat, program pembangunan serta proyek-proyek pembangunan akan gagal.

Anggaran adalah salah satu hal yang sangat penting dalam program pembangunan. tanpa anggaran pembangunan jelas tidak akan bisa berjalan. Setiap tahun pagu anggaran selalu dinaikkan, dan setiap tahun pula kebutuhan pembangunan terus meningkat. Banyaknya program usulan yang mempunyai tingkat kebutuhan sangat penting yang menyebabkan banyak pula program yang tidak dapat terakomodir dalam RKPD karena keterbatasan anggaran. Dalam hal ini program-program yang bisanya tidak dapat masuk dalam RKPD tahun ini, akan masuk long list ataupn dialihkan untuk ditangani oleh OPD (Organisasi Perangkat Daerah).

Hal ini seperti yang diungkapkan oleh Supadmi (2013) dalam penelitian sebelumnya bahwa jumlah dana yang dianggarkan untuk pembangunan hasil kegiatan musrenbang masih kurang mencukupi, hal ini dikarenakan banyak 
program yang harus dijalankan, artinya bahwa semua kegiatan yang sudah diprioritaskan tidak semuanya dapat terlaksana dalam satu tahun anggaran, karena ada yang sifatnya jangka panjang dan pendek.

Perumusan strategi peningkatan persentase realisasi usulan hasil musrenbang dalam RKPD Kecamatan Candisari Kota Semarang menggunakan AHP. Analisis Hierarki Proses (AHP) merupakan suatu metode yang sering digunakan untuk menilai tindakan yang dikaitkan dengan perbandingan bobot kepentingan antara faktor serta perbandingan beberapa alternatif pilihan. Dari hasil analisis AHP yang telah dilakukan diperoleh strategi yang bisa dilakukan untuk meningkatkan persentase realisasi usulan hasil musrenbang dalam RKPD sebagai berikut:

Strategi pemberian sosialisasi kepada masyarakat sebelum dilaksanakan sebenarnya telah dilakukan oleh pemerintah. Dalam hal ini biasanya dilakukan dalam kegiatan rapat RT maupun RW. Adanya sosialisasi diharapkan mampu menjadi edukasi yang sesuai untuk masyarakat dalam mengambil sikap saat musrenbang dilaksanakan, entah dalam pemberian usulan maupun apa yang dimaksud dengan musrenbang itu sendiri.

Sesuai dengan yang dikemukakan Purwandari (2015) dalam penelitian sebelumnya mengatakan bahwa DSP (Daftar Skala Prioritas) yang tersusun dalam waktu semalam pada tahap Musling RT belum tentu mewakili aspirasi seluruh masyarakat, karena kehadiran masyarakat pada forum tersebut belum tentu karena mereka paham dengan tujuan forum tersebut dan permasalahan yang dibahas. Bisa jadi mereka datang hanya berperan secara pasif, yaitu datang, mendengarkan dan menyetujui, tanpa berpendapat. Pada kondisi normal, proses penjaringan aspirasi masyarakat membutuhkan waktu yang cukup lama, karena masyarakat yang terlibat memiliki latar belakang dan sudut pandang yang berbeda-beda terhadap kondisi lingkungan bermukimnya dan terhadap pembangunan partisipatif. Untuk mengatasi kasus yang terjadi dalam penelitian sebelumnya, sosialisasi/pemberian edukasi bagi masyarakat dapat menjadi hal yang berperan besar dalam proses pembangunan. Diharapkan masyarakat mampu berperan aktif dalam mengikuti dan memahami musrenbang juga dalam pengajuan usulan.

Menciptakan rasa memiliki masyarakat dalam pengelolaan pemerintah daerah memiliki arti msyarakat diijinkan tau tentang apa yang terjadi dalam proses pembangunan yang dilakukan oleh pemerintah. Masyarakat diajak terlibat dalam proses penyusunan, pelaksanaan dan pengawasan. Hal ini Conyers (1994) ungkapkan dalam teori partisipasi masyarakat, juga mengungkapkan bahwa pentingnya peran masyarakat dalam perencanaan pembangunan yaitu masyarakat akan memiliki rasa percaya akan program kegiatan pembangunan bila mereka dilibatkan dalam proses persiapan dan perencanaan hingga pelaksanaannya. Masyarakat akan lebih mengerti kondisi program dan kegiatan dan memiliki rasa memiliki (sense of belonging) atas program dan kegitan tersebut (Wirawan, 2015).

Pak Margita dalam wawancara 18 November 2017 mengungkapkan bahwa pelaksanaan musrenbang (pelaksanaan program pembangunan) yang diserahkan kepada pihak ketiga kadang membuat hilangnya kepercayaan masyarakat kepada pihak pelaksana karena nilai dari proyek yang dikerjakan dinilai lebih sedikit daripada anggaran yang telah disediakan.

Hal ini sesuai dengan Swapan (2014) mengungkapkan bahwa:

Citizens' attitude towards participation may be substantially affected by the level of trust they have on planning agencies seeking to engage them to participate. People are highly likely to be 
involved in the planning process who believes their demand will be incorporated in the final plan. Participation cannot be achieved unless such belief does exist.

Sikap masyarakat terhadap partisipasi dipengaruhi oleh tingkat kepercayaan yang mereka miliki pada agen perencanaan. Jika masyarakat diberikan kepercayaan oleh pemerintah daerah, masyarakat akan lebih bisa berpartisipasi secara serius dan aktif dalam proses musrenbang, sehingga masyarakat dapat memberikan usulan-usulan lebih aktif lagi. Hal ini seperti Strategi Partisipasi meurut Burke (2004) dalam Putra (2016) yang menyatakan bahwa masyarakat tidak dipandang sebagai alat mencapai tujuan, melainkan sebagai mitra dalam mencapai tujuan. Masyarakat dapat diajak kerjasama bersama pemerintah untuk bersamasama melaksanakan dan mengamati jalannya proses pembangunan.

Undang-undang No. 32/2004 tentang Pemerintah Daerah meletakan partisipasi masyarakat sebagai elemen penting untuk mencapai tujuan kesejahteraan masyarakat, menciptakan rasa memiliki masyarakat dalam pengelolaan pemerintah daerah, menjamin transparansi, akuntabilas, dan kepentingan umum, perumusan progam dan pelayanan umum yang memenuhi aspirasi masyararakat.

Adanya transparansi, akuntabilitas dan kepentingan umum dalam penyelenggaraan musrenbang sangat diperlukan. Sesuai dengan yang diungkapkan oleh Mahmudi (2010:17) dalam Suryono (2015) Adanya transparansi menjamin akses atau kebebasan bagi setiap orang untuk memperoleh informasi tentang kebijakan, proses pembuatan dan pelaksanaannya, serta hasil-hasil yang dicapai. Transparansi juga memiliki arti keterbukaan oranisasi dalam memberikan informasi kepada pihak-pihak yang menjadi pemangku kepentingan.
Sedangkan akuntabilitas memiliki arti kewajiban untuk memberikan pertanggung jawaban atau menjawab, dan menerangkan kinerja serta tindakan seseorang badan hokum pimpinan suatu organisasi kepada pihak yang memiliki hak atau kewenangan untuk meminta keterangan dan pertanggung jawaban.

Adanya transparansi, akuntabilitas dan mementingkan kepentingan umum membuat tingkat kepercayaan masyarakat akan musrenbang dan pemerintah daerah meningkat. Hal ini akan membuat masyarakat merasa usulanusulan mereka terakomodir dengan baik dan dilaksanakan secara transparan dan bertanggungjawab.

Memfasilitasi/mempedomani tata cara, capaian, prosedur, proses dan mekasnisme penyelenggaraan musrenbang semua terangkum dalam pedoman pelaksanaan rembug warga, dan musyawarah perencaan pembangunan kelurahan dan kecamatan dalam rangka menyusunan rencana kerja pemerintah daerah Kota Semarang yang tertuang dalam Peraturan Walikota Nomor 32 Tahun 2016.

Pedoman atau biasa yang disebt dengan Juklak Juknis ini membantu masyarakat dalam mengetahui apa itu musrenbang, tujuan, fungsi dan bagaimana musrenbang itu dilaksanakan. Dengan adanya Juklak Juknis diharapkan masyarakat bisa lebih aktif dalam memberikan usulan-usulan yang berkualitas dalam musrenbang.

Anggaran menjadi hal yang tidak bisa dilepaskan dari program pembanguan. Karena banyaknya usulan yang juga merupakan kebutuhan peningkatan anggaran merupakan salah satu cara untuk mengakomodir lebih banyak program-program pembangunan yang masuk dalam kategori prioritas. Dalam hal ini peningkatan pagu anggaran sudah dilakukan 
setiap tahun, namun anggaran yang dibutuhkan untuk mengakomodir usulan tidaklah cukup.

Salah satu ciri utama suatu daerah yang mampu melaksanakan otonomi, yaitu kemampuan keuangan daerah, artinya daerah harus memiliki kewenangan dan kemampuan untuk membiayai penyelenggaraan pemerintahannya, dan ketergantungan kepada bantuan pusat harus seminimal mungkin, agar pendapatan asli daerah (PAD) dapat menjadi bagian sumber keuangan terbesar sehingga peranan pemerintah daerah lebih besar hal ini diungkapkan olej Halim (2001) dalam Suseno (2013).

Dalam penelitian sebelumnya menurut Supadmi (2013) kurangnya pendamping atau fasilitator desa yang mampu dan kompeten untuk melaksanakan perencanaan partisipatif menyebabkan prioritas kegiatan terkadang tidak bisa terakomodir dalam sebuah perencanaan pembangunan.

Hal ini diklaim dan disebutkan sebagai salah satu sebab tidak dilakukannya proses pengumpulan data atau analisis situasi dan masalah desa secara partisipatif.

Pembekalan/pelatihan kepada fasilitatorfasilitator musrenbang sangat penting mengingat penyelenggaraan musrenbang diurus oleh para fasilitator. Dengan adannya pembekalan dan pelatihan diharapakan penyelengaraan msurenbang menjadi lebih efektif, efisien dan berkualitas seusai dengan ketentuan. Bukan hanya asal jadi yang penting meneyelnggrakan musrenbang.

Pemberian sosialisasi kepada masyarakat terkait besaran anggaran merupakan suatu bentuk transparansi kepada masyarakat. Hal ini harus dilakukan guna memberi masyarakat pengetahuan tentang anggaran yang didapat harus disesuaikan dengan usulan yang diajukan. Dengan adanya transparansi seperti ini, masyarakat akan lebih menerima jika sekiranya usulan yang mereka ajukan belum dapat diakomodir karena kurangnya pendanaan.

Hal ini sesuai dengan yang diungkapkan Halimah (2017) dalam penelitian terdahulu mengungkapkan bahwa hal lain yang dikeluhkan oleh perwakilan warga adalah tidak adanya informasi dan konfirmasi dari hasil Musrenbangcam, program apa saja yang disepakati dan yang mana yang harus dibiaya secara swadaya masyarakat, prioritas kecamatan dan dibiayai dari APBD, dari mana dana anggarannya, bagaimana cara menindak lanjutinya, siapa yang memverifikasi kegiatan tersebut. Informasi yang diperlukan tersebut tidak sampai kepada masyarakat (Halimah, 2017).

\section{SIMPULAN}

Penyebab rendahnya persentase realisasi usulan hasil musrenbang dalam RKPD di Kecamatan Candisari Kota Semarang yaitu: (1) berkaitan dengan belum adanya keakuratan usulan, masih banyaknya masyarakat yang mengusulkan berbagai keinginan bukan kebutuhan; (2) edukasi masyarakat, masyarakat banyak yang masih belum paham bagaimana jalannya musrenbang dan proses pengusulan program dalam musrenbang: dan (3) kurangnya anggaran, hal ini berkaitan dengan banyaknya kebutuhan-kebutuhan pembangunan yang semakin tahun semakin bertambah, sehingga menyebabkan anggaran terus membengkak dan akhirnya beberapa program tidak dapat terpenuhi.

Hasil analisis dari AHP untuk meningkatkan persentase realisasi usulan hasil musrenbang dalam RKPD di Kecamatan Candisari Kota Semarang adalah aspek Sumber Daya Manusia (SDM) sebagai proritas utama, selanjutnya aspek Regulasi dan yang terakhir 
adalah aspek Anggaran. Adapun alternatif strategi guna untuk meningkatkan persentase realisasi usulan hasil musrenbang dalam RKPD di Kecamatan Candisari Kota Semarang sebagai prioritas utama terpilih pemberian sosialisasi kepada masyarakat sebelum musrenbang dilaksanakan dari aspek SDM, selanjutnya alternatif strategi yang menjadi prioritas kedua dan ketiga berasal dari aspek regulasi yaitu menciptakan rasa memiliki masyarakat dalam pengelolaan pemerintah daerah, dan menjamin terdapatnya transparansi, akuntabilitas dan kepentingan umum.

\section{DAFTAR PUSTAKA}

Asnar. 2016. Partisipasi Masyarakat Dalam Pembangunan Di Kelurahan Sidomulyo Kecamatan Samarinda Ilir Samarinda. Jurnal Studi Sosial, Volume 1 No.2 Hal 121131. Samarinda: Univeristas Mulawarman.

Berliana, Lavinia Elisa dan Amin Pujiati. Analisis Kebijakan Permukiman Liar di Sempadan Banjr Kanal Timur. Economics Development Analysis Journal Vol. 6 No. 3.

Halimah, Ayu dan Ayi Karyana. 2017 Skala Prioritas Perencanaan Pembangunan Dalam Musrenbang Kecamatan. Jurnal Manajemen Pelayanan Publik Vol 1 , No 1 .

Kuncoro, Mudrajad. 2004. Otonomi dan Pembangunan Daerah: Reformasi, Perencanaan, Srategi dan Peluang. Jakarta: Erlangga.

Purwandari, Any Wahyu \& Mussadun. 2015. Studi Partisipasi Masyarakat Pada Pelaksanaan Musyawarah Perencanaan Pembangunan Kelurahan Di Kelurahan Semanggi Kota Surakarta. Volume 11 No. 4 Hal 377390. Semarang: Universitas Diponegoro.
Putra, Dody Prasetyo Perkasa. 2016. Strategi Perencanaan Pembangunan Pertisipatif Di Kota Makassar. Skripsi. Makassar: Fakultas Ilmu Sosial dan Ilmu Politik Universitas Hasanuddin Makassar.

Rahman, Yozi Aulia dan Ayunda Lintang Chamelia. 2015. Faktor-faktor yang Mempengaruhi PDRB Kabupaten/Kota Jawa Tengah 2008-2012. JEJAK Journal of Economics and Policy 8 (1) (2015): 88-99.

Rusdarti dan Fafurida. 2016. Strategi Pengembangan Daerah Growth Pole melalui Pemanfaatan Potensi Lokal. Jurnal Ekonomi dan Bisnis Vol. 19 No.3

Sanjayani, Rita. 2016. Factors Influencing Community Participation in Development Planning through Development Planning Forum (Musrenbang) in Sumbermanjing Wetan District Malang Regency. JPAS Vol. 1, No. 1, pp 16-25.

Supadmi, Utin Sri Ayu, dkk. 2013. Pelaksanaan Hasil Musyawarah Perencanaan Pembangunan (Musrenbang) Di Kecamatan Kapuas Kabupaten Sanggau. Tesis. Program Studi Ilmu Administrasi Negara Program Magister Ilmu Sosial Universitas Tanjungpura Pontianak.

Suseno, Deky Aji. 2013. Efektivitas dan Kemandirian Keuangan Daerah Provinsi Jawa Tengah Pasca Diterapkannya Desentralisasi Fiskal. Economics Development Analysis Journal. Vol. 2 No.2.

Swapan, Mohammad Shahidul Hasan. (2014). Realities of community participation in metropolitan planning in Bangladesh: Acomparative study of citizens and planning Practitioners' perceptions. Jurnal Habitat International pp: 191-197 Australia: Department of Urban and Regional Planning Curtin University.

Wirawan, Ricky dkk. 2015. Partisipasi Masyarakat Dalam Perencanaan Daerah. Jurnal Ilmu Sosial dan Ilmu Politik Vol. 4, No. 2. Malang: Universitas Brawijaya. 